\title{
An update of clinical issues from InSIGHT 2011
}

\author{
L Lipton
}

From Familial Aspects of Cancer 2011 Research and Practice: A combined meeting of kConFab, Australian Breast Cancer Family Study, Australian Colorectal Cancer Family Study, Australian Ovarian Cancer Study, Family Cancer Clinics of Australia and New Zealand and kConFab

Kingscliff, Australia. 23-26 August 2011

The fourth biennial InSIGHT meeting, held from 30th March to 2nd April 2011 in San Antonio Texas was a great success. The meeting was very well organized by hosts Dr Patrich Lynch and Dr Michael Rodriguez Bigas. Topics covered known genetic predispositions to gastrointestinal and other cancers, identification, risk stratification and surveillance and new developments in basic science.

Published: 12 April 2012
Submit your next manuscript to BioMed Central and take full advantage of:

- Convenient online submission

- Thorough peer review

- No space constraints or color figure charges

- Immediate publication on acceptance

- Inclusion in PubMed, CAS, Scopus and Google Scholar

- Research which is freely available for redistribution 